\title{
MANFAAT DATA WAREHOUSE PADA PT ABC
}

\author{
Evaristus Didik M.; Dewi S.; Felisia L.; Winnie S.
}

\author{
Information Systems Department, School of Information Systems, Binus University \\ Jl. K.H. Syahdan No. 9, Palmerah, Jakarta Barat 11480 \\ emadyatmadja@binus.edu
}

\begin{abstract}
The purpose of this paper is to analyze the current system to find out problems faced by the company and propose alternative solutions and generate information needed by management by designing a data warehouse according to the information needs of PT ABC. This research implements analysis and design of data warehouse by Ralph Kimball and Ross cited by Connolly and Begg, known as Nine-Step Methodology. The result obtained is a data warehouse application that may present a multidimensional historical data that can assist the management in decisions. Designing data warehouse at PT ABC makes concise the enterprise data and can be viewed from several dimensions. It helps users analyze data for strategic decision quickly and accurately.
\end{abstract}

Keywords: data warehouse, design, multidimensional

\begin{abstract}
ABSTRAK
Tujuan penulisan ini adalah menganalisis sistem yang sedang berjalan untuk menemukan permasalahan yang sedang dihadapi oleh perusahaan dan mengusulkan alternatif pemecahan masalah serta menghasilkan informasi yang dibutuhkan oleh pihak manajemen dengan merancang data warehouse sesuai dengan kebutuhan informasi di PT ABC. Metode Penelitian yang digunakan adalah analisis dan perancangan data warehouse menurut Ralph Kimball dan Ross yang dikutip oleh Connolly dan Begg yang dikenal dengan Nine-Step Methodology. Hasil yang didapat adalah sebuah aplikasi data warehouse yang dapat menyajikan data historis secara multidimensional sehingga dapat membantu pihak manajemen dalam mengambil keputusan. Perancangan data warehouse pada PT ABC menjadikan data perusahaan menjadi ringkas dan dapat dilihat dari beberapa dimensi yang bertujuan membantu pengguna untuk menganalisis data yang ada untuk pengambilan keputusan yang bersifat strategis secara cepat dan tepat.
\end{abstract}

Kata kunci: data warehouse, perancangan, multidimensional 


\section{PENDAHULUAN}

Data warehouse merupakan tempat penyimpanan data dalam jumlah besar yang berfungsi untuk mendukung pengambilan keputusan. Data warehouse merupakan bagian dari teknologi informasi yang saat ini banyak dipergunakan oleh perusahaan-perusahaan. Dengan data warehouse, data sumber yang beragam yang didapat dari database transaksi perusahaan maupun berasal dari luar perusahaan, diintegrasikan ke dalam sebuah media penyimpanan yang kemudian dapat menghasilkan laporan multidimensional bagi penggunanya.

PT ABC yang bergerak di bidang pengadaan pelumas dengan berbagai merk semakin membutuhkan penanganan yang profesional agar seluruh kegiatan perusahaan dapat berjalan baik dan tujuan dapat tercapai sesuai visi dan misi. Dengan meningkatnya jumlah transaksi dan meluasnya penggunaan sistem informasi menyebabkan terjadi peningkatan jumlah data yang perlu disimpan secara signifikan. Peningkatan data tersebut menimbulkan penurunan performa pada sistem operasional dan upaya mempertahankan data historis dinilai tidak setara dengan manfaat yang diterima karena tidak mampu mengubah data tersebut menjadi informasi yang diperlukan. Oleh karena itu diperlukan analisis dan perancangan data warehouse pada PT ABC sehingga sistem operasional dapat berjalan dengan baik dan data historis dapat dimanfaatkan secara optimal.

Pembuat keputusan membutuhkan akses ke semua sumber data yang ada. Dengan melakukan query ke setiap sumber individual, tentunya menjadi tidak praktis dan tidak efisien. Sumber data mungkin hanya menyimpan data terkini, sementara pembuat keputusan perlu mengakses data-data terdahulu pada perusahaan itu. Misalnya saja informasi mengenai pola penjualan yang berubah dari tahun ke tahun merupakan pertimbangan penting dalam mengambil keputusan. Oleh karena itu data warehouse merupakan solusi bagi masalah ini.

Data warehouse merupakan tempat penyimpanan berukuran besar yang dibuat untuk menyimpan data dari berbagai sumber dan dipelihara oleh beberapa unit operasi berbeda bersamaan dengan transformasi sejarah dan ringkasan data itu sendiri (Hwang \& Xu, 2008). Data warehouse yang telah diimplementasikan dengan baik dapat memberikan keuntungan yang besar bagi organisasi (Conolly dan Begg, 2010).

Sedangkan menurut Lane (2002), data warehouse ialah suatu basis data relasional yang dirancang untuk query dan analisis dibandingkan untuk proses transaksi.

Menurut Kimball dan Ross (2002), Data warehouse adalah sebuah sistem yang mengekstrak, membersihkan, menyesuaikan, dan menyampaikan sumber data ke dalam sebuah tempat penyimpanan data dimensional dan kemudian mendukung dan mengimplementasi query dan analisis untuk tujuan pengambilan keputusan.

Berdasarkan penelitian yang telah dilakukan pada PT ABC, ditemukan beberapa masalah sebagai berikut: (1) kesulitan dalam mengakses data-data pada periode sebelumnya sehingga keputusan yang diambil tidak optimal; (2) data hanya tersimpan tanpa menghasilkan laporan yang berguna bagi perusahaan untuk meningkatkan profit perusahaan; (3) laporan yang dihasilkan hanya menampilkan informasi dari dua dimensi saja. Untuk membandingkan informasi dari beberapa dimensi maka eksekutif harus membandingkannya secara manual; (4) lambat untuk mengakses data pada tahun sebelumnya sehingga keputusan yang diambil tidak optimal karena perusahaan masih mengambil data dari data operasional.

Untuk mengatasi masalah yang terjadi di PT ABC, penelitian ini mengusulkan untuk membangun sebuah aplikasi data warehouse. Keuntungan menggunakan data warehouse adalah: (1) 
informasi yang akan ditampilkan dapat bersifat summary sampai mendetail yang memungkinkan pengguna untuk memperoleh informasi yang bersifat summary sesuai dengan kebutuhan; (2) para eksekutif dapat memperoleh laporan yang memiliki beberapa dimensi dan dapat memilih data yang ingin ditampilkan; (3) pengambilan data historis tidak menggunakan data operasional sehingga lebih mudah dan cepat dalam mengakses data yang akan digunakan untuk pengambilan keputusan.

Tujuan dari penelitian ini adalah: (1) menganalisis sistem yang sedang berjalan dan mengatur jumlah data yang banyak pada perusahaan; (2) identifikasi kebutuhan informasi berdasarkan visi dan misi yang dibutuhkan pihak eksekutif PT ABC yang nantinya berguna untuk perancangan data warehouse; (3) menampilkan laporan untuk dianalisis oleh pihak eksekutif dengan perancangan data warehouse.

Perancangan Data warehouse pada PT ABC menggunakan centralized Data warehouse (Data warehouse terpusat). Sumber data yang terdapat pada database operasional PT ABC akan dipilih berdasarkan jenis pelaporan yang akan dibutuhkan oleh perusahaan, yang kemudian dikumpulkan dan diintegrasikan pada suatu tempat penyimpanan besar.

Dipilihnya arsitektur terpusat (Gambar 1) karena memiliki beberapa keuntungan, yaitu: (1) konsistensi data sangat tinggi karena data-datanya sudah diintegrasikan terlebih dahulu; (2) mempermudah maintenance dari Data warehouse, termasuk pemantauan (Controlling), karena memiliki penyimpanan yang khusus.

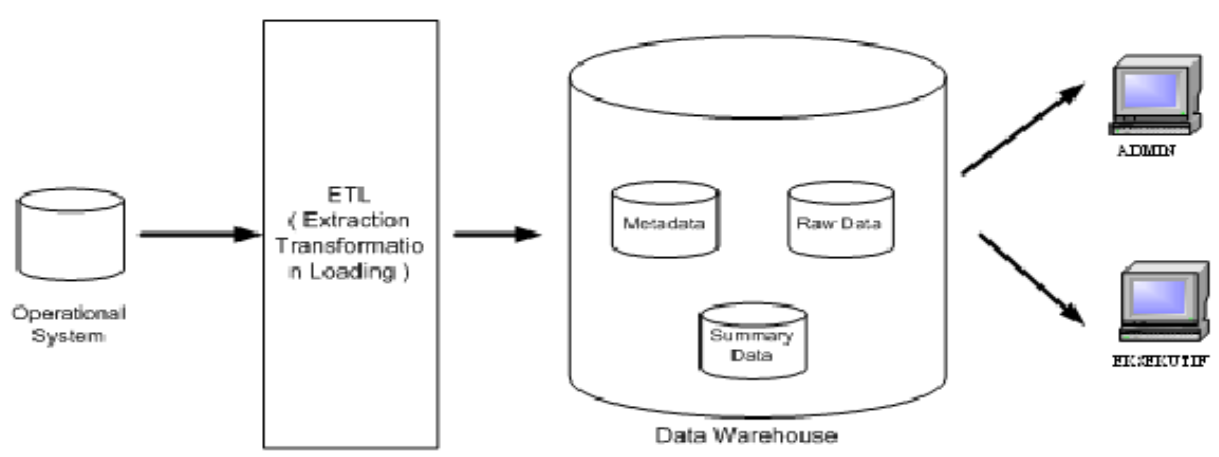

Gambar 1 Arsitektur Data warehouse pada PT ABC

\section{METODE}

\section{Pengumpulan data}

Pengumpulan data dilakukan dengan cara: (1) wawancara, untuk memperoleh informasi mengenai proses bisnis yang berjalan pada PT ABC, kebutuhan user, dan permasalahan yang dihadapi oleh PT ABC; (2) uji dokumentasi dengan melihat formulir-formulir pada PT ABC dan database yang sedang berjalan di PT ABC.

\section{Perancangan}

Perancangan menggunakan nine-step methodology menurut Kimball dan Ross (2002) yang dikutip oleh Connolly dan Begg (2010) dalam bukunya, yaitu: 


\section{Choosing Process}

Berikut proses yang ada pada PT ABC yang akan dipilih untuk perancangan Data warehouse yaitu: penjualan, pembelian, dan retur barang.

\section{Choosing Grain}

Memilih grain berarti menentukan apa yang sebenarnya direpresentasikan oleh record dalam tabel fakta. Berikut adalah grain yang ada dalam perancangan Data warehouse PT ABC: Grain pembelian, Grain penjualan, Grain retur barang.

\section{Identifying and Conforming Dimension}

Pada tahapan ini dilakukan identifikasi dimensi berdasarkan grain yang telah ditentukan pada tahapan sebelumnya. Berikut ini adalah deskripsi perbandingan antara grain dengan dimensi yang dibuat (Tabel $1-3$ ).

Tabel 1 Grain dan Dimensi pada Fakta Penjualan

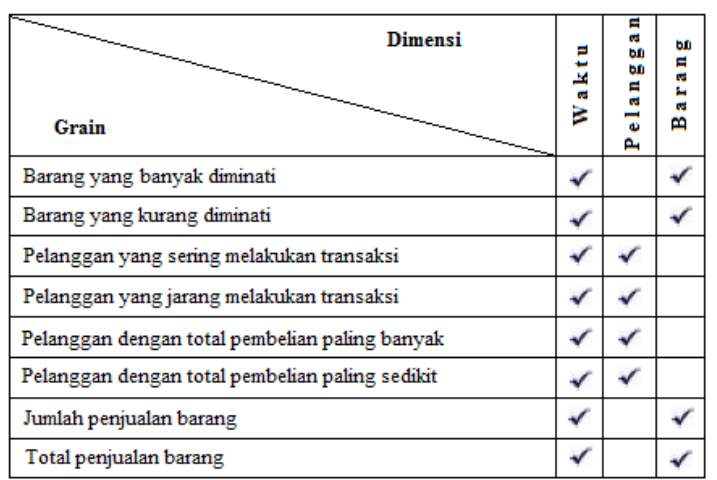

Tabel 2 Grain dan Dimensi pada Fakta Pembelian

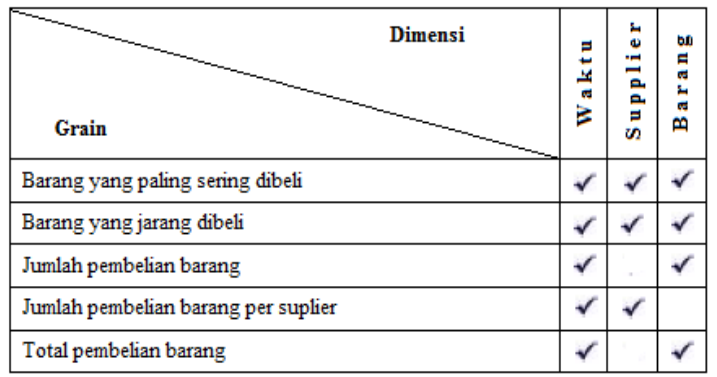

Tabel 3Grain dan Dimensi pada Fakta Retur Barang

\begin{tabular}{|l|c|c|c|}
\hline \multicolumn{1}{|c|}{ Dimensi } & & & \\
Grain & & & \\
\hline Barang dengan jumlah retur paling banyak & & & \\
\hline Barang dengan jumlah retur paling sedikit & $\checkmark$ & $\checkmark$ & $\checkmark$ \\
\hline Jumlah retur per suplier & $\checkmark$ & $\checkmark$ & \\
\hline Jumlah retur barang & $\checkmark$ & & $\checkmark$ \\
\hline Total retur barang & $\checkmark$ & & $\checkmark$ \\
\hline
\end{tabular}




\section{Choosing Facts}

Pada tahap ini akan dilakukan pemilihan fakta yang akan digunakan pada Data warehouse. Fakta yang ada akan diproses dan ditampilkan dalam bentuk grafik. Berikut adalah fakta-fakta yang akan digunakan: penjualan, pembelian, dan retur barang.

\section{Storing Pre-Calculation in Fact Table}

Kalkulasi awal terdapat pada tabel fakta. Pre-kalkulasi yang terdapat dalam tabel fakta. Pertama adalah fakta penjualan, meliputi: (1) jumlah pemesanan, yaitu jumlah barang yang dijual selama periode tertentu; (2) total pemesanan dari seluruh jumlah pemesanan barang dikali dengan harga barang. Kedua adalah fakta pembelian, meliputi: (1) jumlah pembelian, yaitu jumlah barang yang dibeli selama periode tertentu; (2) total PO dari seluruh jumlah pembelian barang dikali dengan harga barang. Ketiga adalah fakta retur barang, meliputi: (1) jumlah retur selama periode tertentu; (2) total retur seluruh jumlah retur barang dikali dengan harga barang.

\section{Rounding out Dimensions Table}

Berikut adalah tabelnya (Tabel 4).

Tabel 4 Rounding out Dimension

\begin{tabular}{ll}
\hline \multicolumn{1}{c}{ DIMENSI } & \multicolumn{1}{c}{ DESKRIPSI } \\
\hline Waktu & Laporan dapat dilihat per hari, bulan, kuartal, tahun. \\
\hline Pelanggan & Laporan dapat dilihat berdasarkan pelanggan. \\
\hline Barang & Laporan dapat dilihat berdasarkan barang. \\
\hline Supplier & Laporan dapat dilihat berdasarkan supplier. \\
\hline BarangMasuk & Laporan dapat dilihat berdasarkan barang masuk. \\
\hline Pembayaran & Laporan dapat dilihat berdasarkan pembayaran. \\
\hline
\end{tabular}

\section{Choosing Duration of Database}

Data warehouse yang dibuat diperkirakan memiliki durasi data kurang lebih empat tahun (Tabel 5). Database yang digunakan merupakan data yang diambil dari OLTP dan dipindahkan ke OLAP melalui proses Data Transform Systems (DTS).

Tabel 5 Durasi Basis Data

\begin{tabular}{lccc}
\hline \multicolumn{1}{c}{$\begin{array}{c}\text { Nama } \\
\text { Aplikasi }\end{array}$} & Database & Data yang Masuk DW & $\begin{array}{c}\text { Data dalam data } \\
\text { warehouse }\end{array}$ \\
\hline Visual & SQL Server 2005 & Oktober 2007- Desember 2007 & 3 bulan \\
\cline { 3 - 4 } Studio & & $2008-2010$ & 3 tahun \\
\cline { 3 - 4 } 2008 & & Januari 2011- Oktober 2011 & 10 ulan \\
\hline
\end{tabular}

\section{Tracking Slowly Changing Dimension}

Berikut adalah penggambaran jika terjadi perubahan dimensi (Gambar 2): 


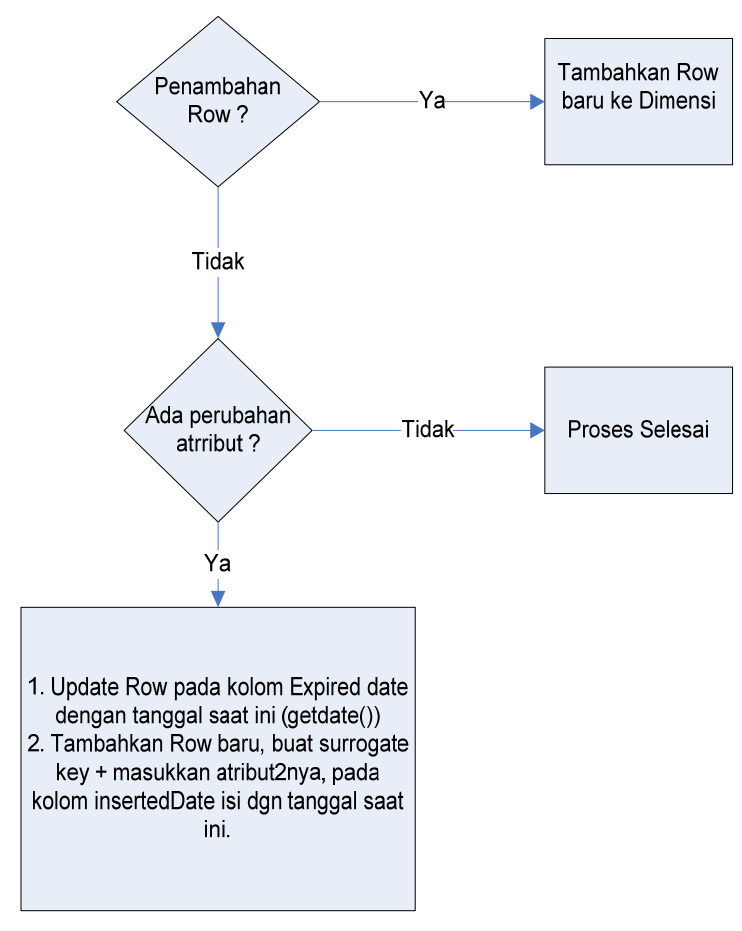

Gambar 2 Flow chart perubahan dimensi perlahan

\section{Deciding Query Priorities and Query Modes}

Proses extract, transformation, and load (ETL) (Tabel 6) akan dilakukan setiap hari oleh staf TI. Apabila terjadi perubahan data pada basis data operasional yang merupakan sumber dari tabel dimensi, akan dilakukan ETL saat terjadi perubahan tersebut.

Tabel 6Extract, Transform, Loading

\begin{tabular}{|c|c|c|}
\hline $\begin{array}{c}\text { Pelaku } \\
\text { ETL }\end{array}$ & $\begin{array}{c}\text { Intensitas } \\
\text { ETL }\end{array}$ & Keterangan \\
\hline $\begin{array}{l}\text { Bagian } \\
\text { EDP }\end{array}$ & Setiap hari & $\begin{array}{l}\text { Proses ETL dilakukan oleh bagian EDP setiap hari nya untuk menjaga } \\
\text { keakuratan data jika sewaktu-waktu dibutuhkan. }\end{array}$ \\
\hline
\end{tabular}

Proses backup akan dilakukan satu minggu sekali oleh staff TI sebelum dilakukan proses ETL. Backup dilakukan untuk mengantisipasi kegagalan dalam proses ETL dan membuat salinan data ke media penyimpanan yang lain untuk mengurangi resiko kehilangan data karena kerusakan hardware, kesalahan user, ataupun bencana alam. Backup yang dilakukan menggunakan tipe full backup di mana data-data pada data warehouse akan disalin ke media penyimpanan lain secara keseluruhan, di mana jika terdapat penambahan data, backup akan menyalin keseluruhan data dan akan me-replace data-data backup yang sebelumnya.

\section{HASIL DAN PEMBAHASAN}

Setelah melakukan analisis terhadap proses bisnis dan database pada PT ABC, informasi yang dibutuhkan oleh para eksekutif adalah sebagai berikut: 


\section{Skema Bintang (Star Scheme)}

Skema bintang yang dirancang mencakup tiga fakta: pembelian, penjualan, dan retur barang. Skema bintang dibuat berdasarkan tabel pada rancangan ERD usulan. Dalam setiap dimensi masingmasing dibuat primary key baru yang dinamakan surrogate key untuk dihubungkan pada tabel fakta sebagai penanda unik baru yang bukan merupakan turunan dari tabel manapun (Gambar 3). Kemudian dimensi pada setiap skema bintang diambil berdasarkan tabel pada ERD usulan tetapi hanya beberapa atribut tertentu yang dibutuhkan dan yang nantinya akan digunakan sebagai pembanding dalam pengambilan keputusan oleh pihak manajemen.

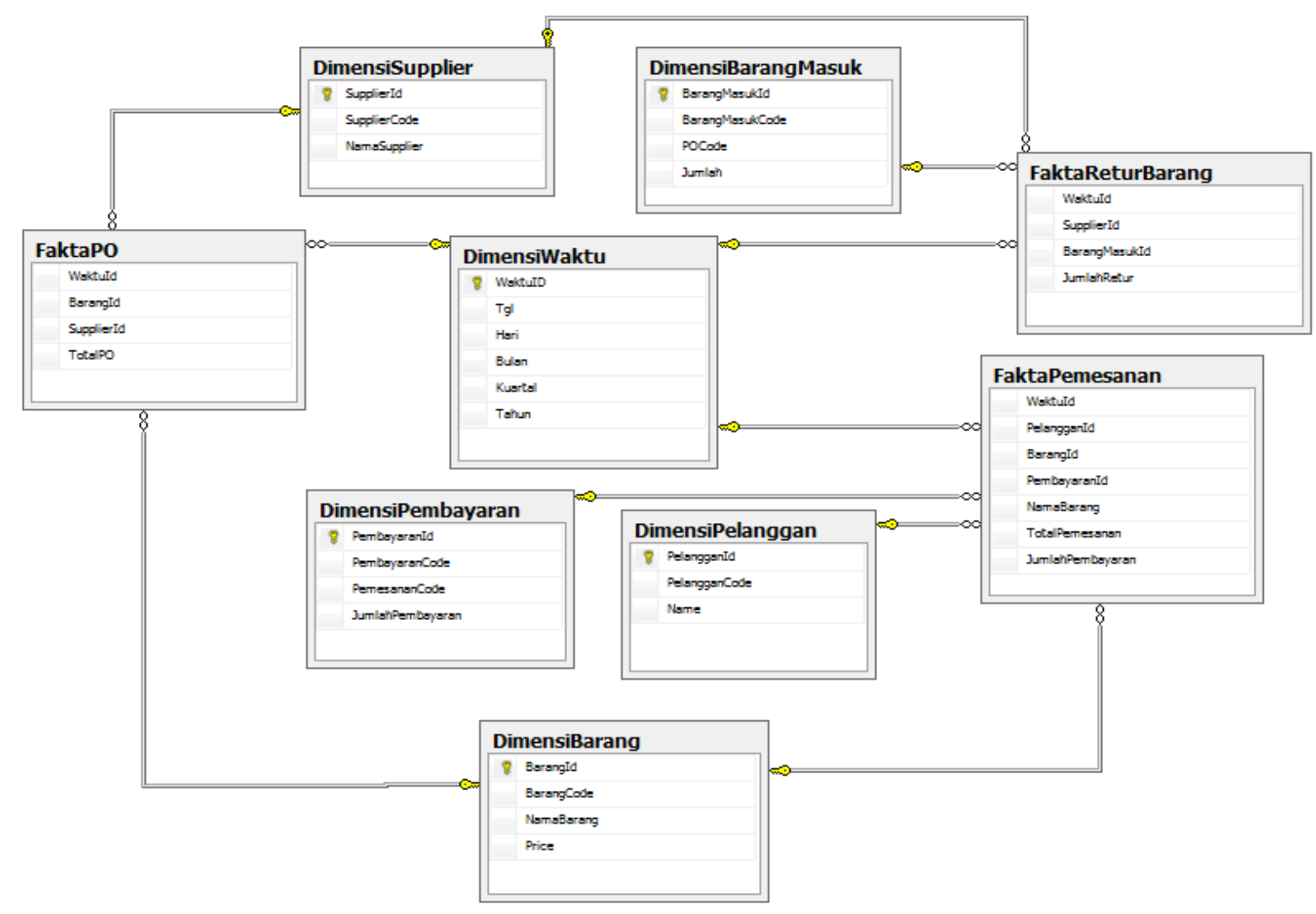

Gambar 3 Dimensional model pada data warehouse PT ABC

\section{Form Pivot \& Chart}

Form Pivot \& Chart ini berisi tampilan hasil transformasi Data warehouse dalam bentuk grafik. Dalam form ini user dapat mengatur tampilan sesuai keinginan berdasarkan menu yang disediakan dalam form, seperti chart type untuk memilih tipe chart. Untuk menampilkan grafik dari data yang ada, user hanya perlu melakukan drag and drop dari pilihan dimensi yang tersedia di atas, untuk kemudian dipindahkan ke bawah, selanjutnya user tinggal melakukan block pada data dalam tabel yang kemudian akan muncul pada kolom graphic tepat di bawah tabel yang tersedia.

\section{Laporan Penjualan}

Menu laporan penjualan (Gambar 4) menampilkan kode-kode barang apa saja yang dipesan, pelanggan mana yang memesan, kapan pemesanan dilakukan, serta tanggal pembayaran. 


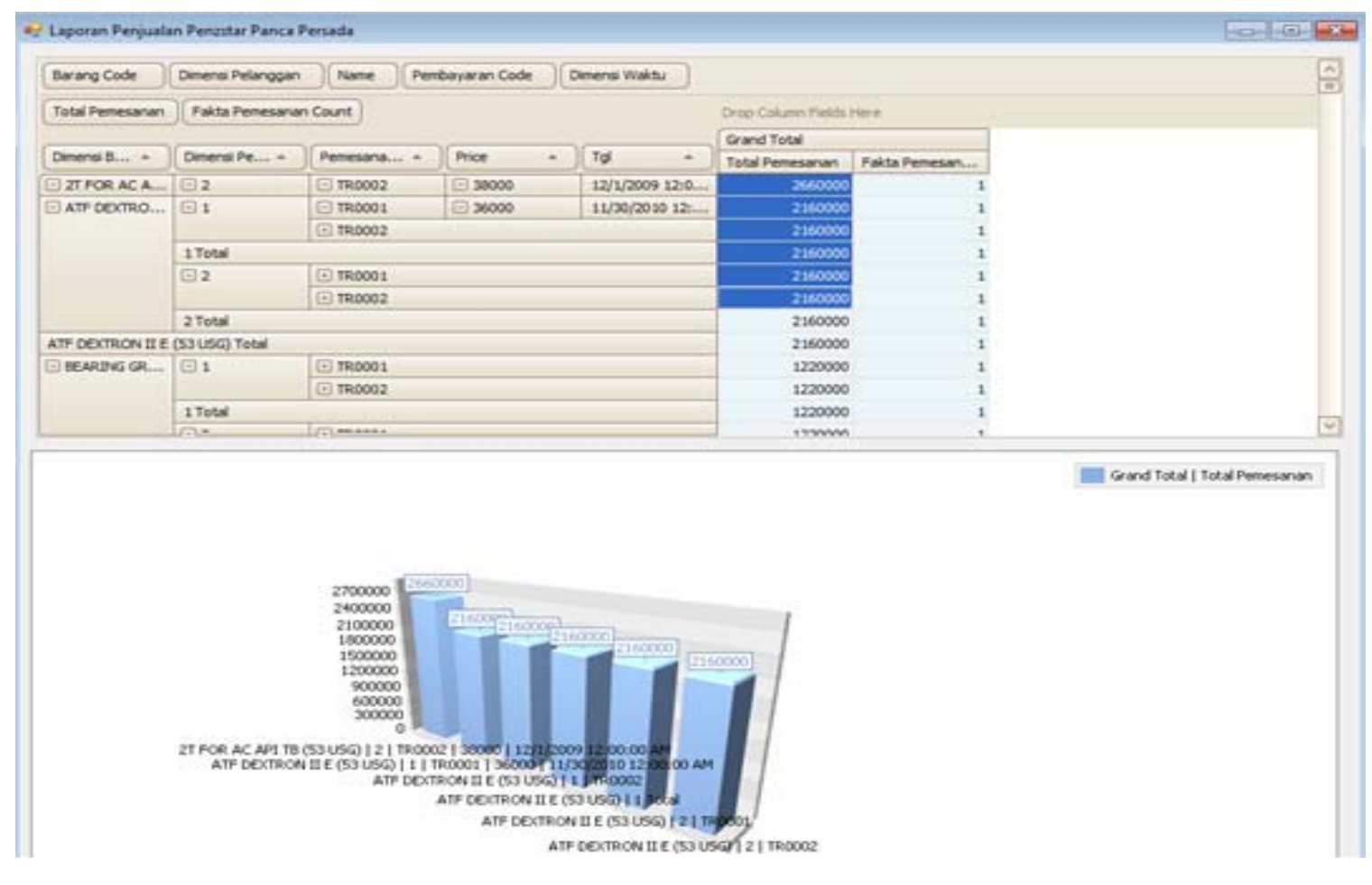

Gambar 4 Tampilan laporan penjualan

\section{Laporan Purchase order}

Menu laporan PO (Gambar 5) menampilkan supplier-supplier yang dimiliki oleh PT ABC, serta tanggal pembuatan PO.

\section{Laporan Retur Barang}

Menu laporan retur barang (Gambar 6) menampilkan kode-kode barang yang sudah diterima berdasarkan PO, jumlah barang yang masuk, jumlah barang yang ingin diretur, serta supplier-supplier yang bertanggung jawab. 


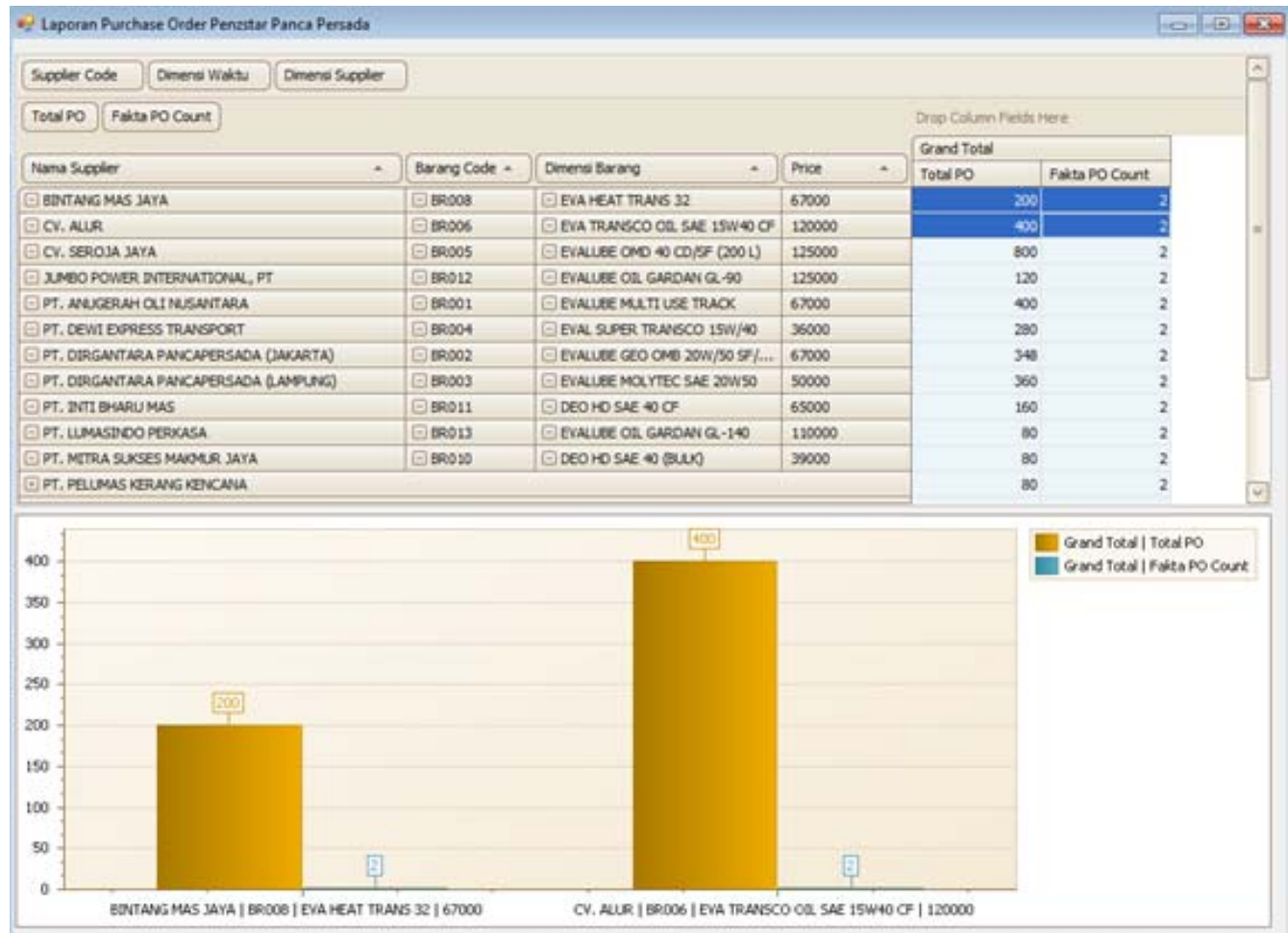

Gambar 5 Tampilan laporan purchase order

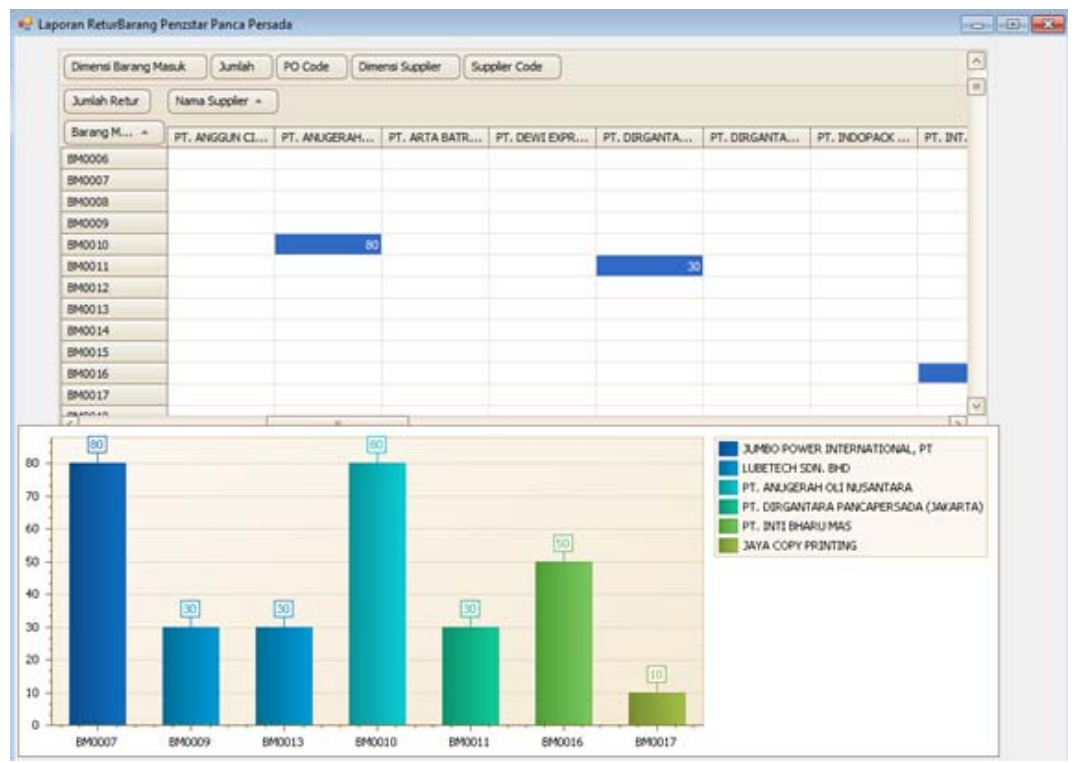

Gambar 6 Tampilan laporan retur barang

\section{PENUTUP}

Setelah melakukan analisis pada PT ABC yang kemudian dilakukan perancangan data warehouse, dapat ditarik beberapa simpulan sebagai berikut: (1) dengan dibuatnya Data warehouse pihak manajemen Rumah Sakit ABC dapat mengambil keputusan dengan lebih cepat dan cermat 
karena database yang ada sudah diperbaiki dan grafik yang ditampilkan pada Data warehouse membuat tampilan report menjadi lebih simpel dan kompak, memudahkan para eksekutif untuk membacanya; (2) data warehouse yang dibuat merupakan hasil proses data yang memiliki dimensi yang bervariasi, sehingga pihak manajemen PT ABC mendapatkan sudut pandang yang lebih bervariasi dalam melakukan proses pengambilan keputusan; (3) dengan dibuat nya data warehouse ini, pihak manajemen PT ABC mendapatkan summary dari data yang ada sehingga pihak eksekutif dapat mengambil keputusan dengan lebih cepat dan tepat.

\section{DAFTAR PUSTAKA}

Connolly, Thomas and Begg, Carolyn. (2010). Database Systems: A Practical Approach to Design, Implementation, and Management (fifth ed.). Boston: Addison Wesley.

Hwang \& Xu. (2008 ). A strucktural model of data warehousing success. The Journal of Computer Information Systems, 48.

Kimball, Ralph. and Ross, Margy. (2002). The data warehouse Toolkit: The Complete Guide to Dimensional Modeling (2nd ed.). Ontario: John Wiley and Sons. 